DAMASCENO JCA; SOARES ACF; JESUS FN; SANT'ANA RS. 2015. Sisal leaf decortication liquid residue for controlling Meloidogyne javanica in tomato plants. Horticultura Brasileira 33: 155-162. DOI - http://dx.doi.org/10.1590/S0102-053620150000200004

\title{
Sisal leaf decortication liquid residue for controlling Meloidogyne javanica in tomato plants
}

\section{Josilda CA Damasceno; Ana CF Soares; Fábio N Jesus; Rosane S Sant'Ana}

UFRB-CCAAB, R. Rui Barbosa, 44380-000 Cruz das Almas-BA; josildadamasceno@gmail.com; ferminosoares@gmail.com; fabiorock222@yahoo.com.br; rosa_silvas@hotmail.com

\begin{abstract}
The effect of sisal liquid residue (fresh and fermented) was evaluated in controlling the root-knot nematode (Meloidogyne javanica) in tomato plants. Bioassays were conducted in vitro with $100 \mu \mathrm{L}$ of an aqueous suspension containing 300 juveniles (J2) of $M$. javanica and $1000 \mu \mathrm{L}$ of sisal liquid residue. The treatments consisted of nematode immersion for 24 and 48 hours in sisal liquid residue, fresh or fermented, diluted in water to the final concentrations of 0 , $2.5,5,7.5,10,12.5,15,17.5$ and $20 \%$, and nematicide Carbofuran at $350 \mathrm{mg} / \mathrm{L}$ of the active ingredient. Under greenhouse conditions, 4000 juveniles of $M$. javanica were inoculated on tomato plants grown in pots, and after one week, $100 \mathrm{~mL}$ of sisal liquid residue at concentrations of $0,4,8,12,16$ and $20 \%$, were added to soil around the tomato plants. Control treatments received either 100 $\mathrm{mL}$ of distilled water or $0.5 \mathrm{~g}$ of Carbofuran per pot. Forty days after inoculation, plants were harvested and evaluated for plant growth and root damage. In addition, the selective effect of sisal liquid residue on growth of beneficial soil microorganisms was evaluated. All concentrations of sisal liquid residue presented nematicidal effect, after $48 \mathrm{~h}$ of nematode exposure. A mortality rate of $100 \%$ was obtained for M. javanica juveniles exposed to liquid residue at a concentration of $20 \%$. Application of increasing concentrations of both sisal liquid residues reduced the number of galls and egg masses per plant and per gram of roots, as well as the final population of M. javanica in soil. Growth of beneficial soil microorganisms was observed in soil amended with sisal fresh liquid residue, for all concentrations tested. The fermented residue caused inhibition of soil beneficial microorganisms. Future studies should be conducted to test the nematicidal effect on tomato plants under field conditions.
\end{abstract}

Keywords: Solanum lycopersicum, Agave sisalana, root-knot nematode.

\section{RESUMO}

Resíduo líquido do desfibramento de folhas de sisal no controle de Meloidogyne javanica em tomateiro

Este trabalho teve o objetivo de avaliar o efeito do resíduo líquido (fresco e fermentado) de sisal no controle de Meloidogyne javanica em tomateiro. Foram conduzidos bioensaios in vitro com $100 \mu \mathrm{L}$ de suspensão aquosa contendo 300 juvenis (J2) de M. javanica e 1000 $\mu \mathrm{L}$ de resíduo líquido. Os tratamentos consistiram do resíduo líquido fresco e fermentado, nas concentrações de 2,5, 5, 7,5, 10, 12,5, 15, 17,5 e $20 \%$, o controle sem resíduo e o nematicida Carbofuran a 350 $\mathrm{mg} / \mathrm{L}$ do i.a., com a imersão dos $\mathrm{J} 2$ nestes tratamentos, por 24 e 48 horas. Em casa de vegetação, 4000 juvenis de $M$. javanica foram inoculados em tomateiro e, após uma semana, foram vertidos na base da planta $100 \mathrm{~mL}$ do resíduo líquido de sisal nas concentrações de 0 , $4,8,12,16$ e 20\%, além da água destilada e o nematicida Carbofuran a $0,50 \mathrm{~g}$ por vaso, como testemunhas. Foram analisados o crescimento vegetativo e os danos nas raízes. Avaliou-se a seletividade do resíduo do sisal sobre micro-organismos benéficos do solo. Todas as concentrações do resíduo apresentaram efeito nematicida nos testes in vitro, após 48 horas de exposição dos nematoides, ocorrendo até $100 \%$ de mortalidade dos juvenis de $M$. javanica na concentração de $20 \%$. O aumento das concentrações do resíduo fresco ou fermentado reduziu o número de galhas e massas de ovos por planta e por grama de raízes e também a população final de $M$. javanica no solo. Houve crescimento dos micro-organismos benéficos nos tratamentos com resíduo fresco de sisal, para todas as concentrações avaliadas. O resíduo fermentado inibiu o crescimento de micro-organismos benéficos do solo. Estudos futuros serão conduzidos visando comprovar a ação nematicida deste resíduo no controle de $M$. javanica em tomateiro a campo.

Palavras-chave: Solanum lycopersicum, Agave sisalana, nematoidedas-galhas.

\section{(Recebido para publicação em 4 de setembro de 2013; aceito em 27 de novembro de 2014) (Received on September 4, 2013; accepted on November 27, 2014)}

$\mathrm{T}$ he root-knot nematodes belonging to the Meloidogyne genus are major pathogens of tomato plants (Solanum lycopersicum). Plants under severe nematode attack show reduction in plant height and in functional root system efficiency (Cantu et al., 2009).

Nematode control is a difficult task, mainly because of limitations of most control methods. Chemical control with nematicides can cause damage to the environment and human heath, and crop rotation is a very difficult method for controlling Meloidogyne species due to the wide host range of this genera of plant parasitic nematodes. The use of resistant varieties, while desirable, is limited due to scarcity of resistant cultivars and selection for resistancebreakage at high temperatures (Neves et al., 2008).

Compounds of plant origin may constitute important control agents of pests and pathogenic microorganisms, 
since they can be easily obtained and utilized by farmers, are cost effective, and cause less impact to the environment, when compared to synthetic chemical products (Morais et al., 2009). In this context, the sisal (Agave sisalana) leaf decortication liquid residue can be an alternative for nematode control, being of low cost and without environmental contamination risks.

Sisal, a native plant from Mexico, has adapted well to the semiarid regions in the state of Bahia, Brazil, being the main source of income of most rural families in this region. Brazil is the largest sisal fiber producer and exporter in the world, and in 2011, the state of Bahia was responsible for $95.5 \%$ of sisal production in Brazil (CONAB, 2013). However, sisal fiber only represents $4 \%$ of sisal leaf fresh weight, and the remaining $96 \%$ are solid and aqueous residues with $81 \%$ of liquid residue (Suinaga et al., 2006), which are left as piles of sisal residue on farms without any use.

Sisal liquid residue is composed of secondary metabolites such as alkaloids, phenolic compounds, coumarins, saponins, flavonoids and tannins (Barreto et al., 2010; Botura et al., 2013). These substances are mainly related to plant defense mechanisms, and may present nematicidal activity (Chitwood, 2002). Plants of the genera Agave have biocidal activity against nematodes from goats and lambs (Domingues et al., 2010; Botura et al., 2011, 2013; Silveira et al., 2012), mites (Barreto et $a l ., 2010)$ and plant pathogenic fungi (Guleria \& Kumar, 2009). In addition, the saponins biological activities are related to their ability to form complexes with steroids, proteins and membrane phospholipids, which cause a disruption of their structure and an increase in cell permeability (Schenkel et al., 2010). The biocidal activity of flavonoids against parasites has been linked to alterations of several enzymes and cell metabolic processes (Kerboeuf et al., 2008).

In this study, we aimed to evaluate the sisal liquid residue (fresh and fermented) for the control of Meloidogyne javanica under in vitro conditions and in tomato plants under greenhouse conditions.

\section{MATERIAL AND METHODS}

Meloidogyne javanica eggs and second stage juveniles (J2) -The nematode eggs were extracted from tomato plant roots, inoculated and grown under greenhouse conditions, by using the method described by Hussey \& Barker (1973), and modified by Boneti \& Ferraz (1981). The aqueous suspension of eggs/juveniles was counted in a Peter's chamber, under a microscope, and the suspension was adjusted to the desired concentration by dilution with distilled water.

Sisal liquid residue - The fresh sisal residue (mixed solid and liquid material) was obtained during the sisal leaf decortication process, in a rural property located in the city of Valente, Bahia state, and transported immediately to the laboratory at UFRB in styrofoam boxes with ice. In the laboratory, this mixture was filtered tree times with a 400 mesh sieve and kept in a freezer at $-20^{\circ} \mathrm{C}$, until its utilization for the in vitro and in vivo studies. For the fermented residue, a portion of the fresh liquid residue was mixed with water in a ratio of $1: 1(\mathrm{v}: \mathrm{v})$ and maintained in plastic bottles for 4 days, at room temperature $\left(25 \pm 2^{\circ} \mathrm{C}\right)$, without agitation. After this period, the mixture was filtered in a 400 mesh sieve. The fresh and fermented residues had a $\mathrm{pH}$ value of 5.0 and 9.0, respectively, and both were adjusted with $\mathrm{NaOH}(10 \%)$ and $\mathrm{HCl}(1 \%)$ to a $\mathrm{pH}$ value of 6.5.

In vitro control of Meloidogyne javanica with sisal liquid residue The in vitro tests were conducted at the UFRB Laboratory of Agricultural Microbiology, using a completely randomized experimental design, with ten treatments and eight replications. Each bioassay was conducted in a microcentrifuge tube, which was considered as an experimental plot. The microcentrifuge tubes were filled with $100 \mu \mathrm{L}$ of an aqueous suspension containing $300 \mathrm{~J} 2$ of $M$. javanica and $1000 \mu \mathrm{L}$ of sisal liquid residue (fresh or fermented). The following concentrations were utilized: $0.0 \%$ (negative control with water), 2.5 , $5,7.5,10,12.5,15,17.5$ and $20 \%$ of liquid residue diluted in sterile distilled water (concentrations defined by preliminary tests). The positive control was prepared with the synthetic nematicide Carbofuran (Furadan 350 $\mathrm{SC}$, at $350 \mathrm{~g}$ active ingredient per $\mathrm{L}$ ), as described by Nasu et al. (2010).

The bioassays were incubated at $28^{\circ} \mathrm{C}$, in a growth chamber, and after 24 and $48 \mathrm{~h}$ of nematode exposure, the nematodes were removed from this suspension with the use of a sieve; they were washed with sterile water, and transferred to a Peter's chamber. The immobile individuals were counted under a microscope, and these nematodes were again incubated in water for $24 \mathrm{~h}$. After this incubation period, a sodium hydroxide aqueous solution drop (1.0 M) was added to each tube and the individuals were counted, being the straight and immobile ones considered dead, while the curled and mobile ones were considered alive. The data were transformed into arcsen $(\mathrm{x} / 100)^{0.5}$ and the analysis of variance and linear regression were performed to evaluate the effect of different concentrations of sisal residue on nematode control. The orthogonal contrasts analysis was performed comparing the type of residue (fresh and fermented) and the nematicide concentrations.

Meloidogyne javanica control in tomato plants with sisal liquid residue - The experiment with fresh and fermented sisal residue was conducted under greenhouse conditions. A mixture of soil and sand (proportion of 1:1 $\mathrm{v} / \mathrm{v}$ ) that had been sterilized in an autoclave at $120^{\circ} \mathrm{C}$ for $1.5 \mathrm{~h}$ twice on separate days, was used in pots with $2 \mathrm{~L}$ capacity. Tomato plants cv. 'Santa Cruz Kada' were transplanted after they had been grown for 20 days in Vivatto Slim ${ }^{\circledR}$ substrate. Only one plant was transplanted per pot. Seven days after transplantation, the tomato plants were inoculated with 4000 individuals of $M$. javanica. One week after inoculation, $100 \mathrm{~mL}$ of fresh or fermented sisal liquid residue were poured into each pot, in the soil surface around plant stem.

The experimental design was in randomized blocks, in a $2 \times 6+2$ factorial scheme (fresh and fermented residue $x$ residue concentrations) and two 
control treatments (distilled water and nematicide), with 15 replications. Each pot with one tomato plant was considered an experimental unit. The pots were amended with the sisal liquid residue diluted in water at $4,8,12,16$ and $20 \%$, plus distilled water as the negative control and Carbofuran nematicide (Furadan $350 \mathrm{SC}$ ) at $0.5 \mathrm{~g}$ dosage per pot, according to Nasu et al. (2010), with modifications. These authors utilized $2.0 \mathrm{~g}$ of Furadan $350 \mathrm{SC}$ per pot, which caused phytotoxicity when tested in our studies with tomato plants. Therefore, the nematicide concentration was reduced to $0.5 \mathrm{~g}$, after being tested in previous experiments.

Forty days after nematode inoculation, the plants were harvested and evaluated for height; stem diameter; shoot and root dry weight; number of galls and egg masses. Fresh root samples were separated and stained by immersion in acid fuchsin at $0.15 \%$ for 20 min for counting root galls and egg masses. The total number of nematodes in soil (final population $=\mathrm{Pf}$ ) was calculated by counting the individuals in $100 \mathrm{~mL}$ of soil and by multiplying the number of nematodes by a factor of 20 , to obtain the total number in 2 L of soil per pot, which represented an experimental unit. The reproductive factor $(\mathrm{FR}=\mathrm{Pf} / \mathrm{Pi})$ was calculated from these data (Oostenbrink, 1966).

The data were analyzed by a variance and regression analysis to evaluate the effect of the different residue concentrations. The orthogonal contrast analysis was performed to compare the residue concentrations and the positive control with the nematicide. The SISVAR statistical software was used. All experiments were repeated.

Selectivity of the sisal liquid residue for beneficial microorganisms - The fresh and fermented sisal residue effect on growth of soil beneficial microorganisms was evaluated. The residues, after being filtered, were sterilized by exposure for $40 \mathrm{~min}$ under UV light, in a laminar flow cabinet. The following microorganisms were tested: Penicillium citrinum, Trichoderma atroviride, T. harzianum, T. virens, and also 10 isolates of actinobacteria belonging to the Streptomyces genera, and identified by the following codes: BFT 4, BFT 7, BFT 11, BFT 41, BFT 71, BFT 87, BFT 88, BFT 102, BFT 106 , and PD3. These microorganisms were selected for this study from the Microbiology Laboratory culture collection at UFRB, and the selection was based on biological control studies with Aspergillus niger and M. javanica (Damasceno, 2011; Damasceno et al., 2012; Sá, 2013).

The microorganisms were multiplied in specific culture media for their growth. The CYA (Czapeck Yeast extract Agar) media and Czapeck Dox media were prepared according to the manufacturer's recommendations. The modified TSM media was prepared with the following ingredients: $0.2 \mathrm{~g}$ of $\mathrm{MgSO}_{4} .7 \mathrm{H}_{2} \mathrm{O} ; 0.9 \mathrm{~g}$ of $\mathrm{KH}_{2} \mathrm{PO}_{4} ; 0.15 \mathrm{~g}$ of $\mathrm{KCl} ; 1 \mathrm{~g}$ of $\mathrm{NH}_{4} \mathrm{NO}_{3} ; 3 \mathrm{~g}$ of dextrose; $0.15 \mathrm{~g}$ of rose bengal; $3 \mathrm{~mL}$ of Triton $\mathrm{X} 100 ; 0.25 \mathrm{~g}$ of chloramphenicol; 0.1 $\mathrm{mg}$ of Carbendazin and $15 \mathrm{~g}$ of Agar. The amount of water used to prepare the culture media was reduced according to the residue volume that was added to the culture media, to obtain a final volume of $1 \mathrm{~L}$.

The different concentrations of fresh or fermented residue $(4,8,12$, 16 and $20 \%$ ) were added to the sterile culture media, in the liquid phase, at a temperature close to the melting point (at approximately 45 to $50^{\circ} \mathrm{C}$ ). After residue addition, the culture media was carefully shaken manually with circulatory movements for homogenization, and was transferred to Petri plates. Cycloheximide $(100 \mu \mathrm{g} /$ $\mathrm{mL}$ ) was added to Czapeck Dox media for fungi growth inhibiting. The same culture media without residue addition were used for the control treatment. The Petri plates were inoculated with the microbial cultures and incubated at room temperature $\left(28^{\circ} \mathrm{C}\right)$ for 5 to 10 days. The presence or absence of microbial growth was recorded.

\section{RESULTS AND DISCUSSION}

In vitro control of Meloidogyne javanica sisal liquid residue - The sisal liquid residues, both fresh and fermented, reduced the mobility and caused significant mortality among the juveniles of $M$. javanica. After $24 \mathrm{~h}$ of exposure, immobility of juveniles increased linearly with increasing concentrations of both residues. Immobility rates of up to $97.3 \%$ and $92.1 \%$ were obtained for $M$. javanica with the use of fresh and fermented residues, respectively, both at a concentration of $20 \%$, when compared to the immobility rates (approximately $4 \%$ ) observed for the negative control treatment without the residue $(0 \%)$ (Figure 1A).

After 48 h of exposure of M.javanica to the treatments, the nematicidal effect of sisal residues was proven for all tested concentrations. The nematodes when transferred to water, after exposure to the sisal residues, did not recover their mobility and died. The mortality rate of $M$. javanica exposed to both residues for $48 \mathrm{~h}$ increased with the increasing residue concentrations. Mortality rates ranged from $90.8 \%$ to $100 \%$ and $95 \%$ to $100 \%$, at concentrations between $2.5 \%$ and $20 \%$ of fresh and fermented residue, respectively (Figure $1 \mathrm{~B}$ ). The synthetic nematicide caused $99.8 \%$ nematode mortality after exposure for $48 \mathrm{~h}$, showing no significant difference $(p \leq 0.01)$ when compared to the mortality rates obtained with both residues at $17.5 \%$ and $20 \%$ concentrations.

Forty-eight hours was shown to be an appropriate time for $M$. javanica exposure to the residue, and also to the synthetic nematicide, for efficient nematode control. Preliminary tests (data not shown) have indicated that $72 \mathrm{~h}$ of nematode exposure to these treatments did not present any significant difference with regard to efficient nematode control, when compared to the results observed for $48 \mathrm{~h}$ of exposure. For the period of $48 \mathrm{~h}$ of exposure, the fresh and fermented residues at the concentrations of $17.5 \%$ and $20 \%$ caused mortality rates similar to those observed for the synthetic nematicide, with values between $98 \%$ and $100 \%$, without significant differences between the residues and the synthetic nematicide (Figure 1B).

A comparison by orthogonal contrasts of the effect of the treatment with sisal residues (fresh and fermented) 
Table 1. Estimates of contrasts (nematicide $\mathrm{x}$ fresh and fermented sisal liquid residue concentrations) and significance for the evaluated factors of the in vitro control of Meloidogyne javanica (after 24 and $48 \mathrm{~h}$ ) and in vivo plant height (PH), stem diameter (SD), shoot dry weight (SDW), root dry weight (RDW), nematode final population (FP), root gall number (GN), egg mass (EM), and factor of reproduction (FR) of tomato plants infected with Meloidogyne javanica \{estimativas de contrastes (nematicida x concentrações de resíduo líquido de sisal, fresco e fermentado) e significância para os fatores avaliados do controle in vitro de Meloidogyne javanica (após 24 e 48 h) e in vivo altura das plantas ( $\mathrm{PH}$ ), diâmetro do caule (SD), massa seca da parte aérea (SDW), massa seca de raízes (RDW), população final de nematóides (FP), número de galhas nas raízes (GN), massa de ovos (EM) e fator de reprodução (FR) de plantas de tomateiro infectadas com Meloidogyne javanica\}. Cruz das Almas, UFRB, 2012.

\begin{tabular}{|c|c|c|c|c|c|}
\hline \multirow{2}{*}{$\begin{array}{l}\text { Contrasts } \\
(\%)\end{array}$} & \multicolumn{5}{|c|}{ Mortality } \\
\hline & \multicolumn{3}{|c|}{24 (hours) } & \multicolumn{2}{|c|}{48 (hours) } \\
\hline 2.5 & \multicolumn{3}{|c|}{$-2.04^{\text {ns }}$} & \multicolumn{2}{|c|}{$-6.28^{* *}$} \\
\hline 5.0 & \multicolumn{3}{|c|}{$-2.22^{\mathrm{ns}}$} & \multicolumn{2}{|c|}{$-5.69^{* *}$} \\
\hline 7.5 & \multicolumn{3}{|c|}{$18.64^{* *}$} & \multicolumn{2}{|c|}{$-4.44^{* *}$} \\
\hline 10.0 & \multicolumn{3}{|c|}{$24.72^{* *}$} & \multicolumn{2}{|c|}{$-5.72^{* *}$} \\
\hline 12.5 & \multicolumn{3}{|c|}{$52.99^{* *}$} & \multicolumn{2}{|c|}{$-2.49^{* *}$} \\
\hline 15.0 & \multicolumn{3}{|c|}{$65.51^{* *}$} & \multicolumn{2}{|c|}{$-2.05^{* *}$} \\
\hline 17.5 & \multicolumn{3}{|c|}{$74.64^{* *}$} & \multicolumn{2}{|c|}{$0.40^{\text {ns }}$} \\
\hline \multirow[t]{2}{*}{20.0} & \multicolumn{3}{|c|}{$77.91^{* *}$} & \multicolumn{2}{|c|}{$0.41^{\mathrm{ns}}$} \\
\hline & PH & SD & SDW & RDW & FP \\
\hline 4.0 & $46.50^{* *}$ & $0.09^{* *}$ & $5.41^{* *}$ & $1.08^{* *}$ & $7763.64^{* *}$ \\
\hline 8.0 & $45.99^{* *}$ & $0.12^{* *}$ & $5.55^{* *}$ & $1.09^{* *}$ & $7477.92^{* *}$ \\
\hline 12.0 & $45.71^{* *}$ & $0.10^{* *}$ & $4.90^{* *}$ & $1.02^{* *}$ & $5570.78^{* *}$ \\
\hline 16.0 & $44.50^{* *}$ & $0.14^{* *}$ & $5.36^{* *}$ & $1.09^{* *}$ & $4792.21^{* *}$ \\
\hline \multirow[t]{2}{*}{20.0} & $46.06^{* *}$ & $0.09^{* *}$ & $5.19^{* *}$ & $0.84^{* *}$ & $3685.07^{* *}$ \\
\hline & GN/plant & GN/g root & EM/plant & EM/g of root & FR \\
\hline 4.0 & $170.82^{* *}$ & $10.77^{* *}$ & $44.47^{* *}$ & $2.26^{\mathrm{ns}}$ & $1.94^{* *}$ \\
\hline 8.0 & $185.39^{* *}$ & $9.42^{* *}$ & $40.90^{* *}$ & $1.68^{\mathrm{ns}}$ & $1.87^{* *}$ \\
\hline 12.0 & $165.82^{* *}$ & $6.83^{* *}$ & $36.47^{* *}$ & $0.66^{\mathrm{ns}}$ & $1.39^{* *}$ \\
\hline 16.0 & $156.82^{* *}$ & $6.57^{* *}$ & $22.69^{\text {ns }}$ & $-0.33^{\mathrm{ns}}$ & $1.20^{* *}$ \\
\hline 20.0 & $125.75^{\text {** }}$ & $5.15^{* *}$ & $29.33^{\mathrm{ns}}$ & $0.29^{\mathrm{ns}}$ & $0.92^{* *}$ \\
\hline
\end{tabular}

**,*Significant at $1 \%(\mathrm{p} \leq 0.01)$ and $5 \%(\mathrm{p} \leq 0.05) \mathrm{ns}=$ not significant at $5 \%(\leq 0.05)$.

Table 2. Plant height (PH), stem diameter (SD), shoot dry weight (SDW), root dry weight (RDW), root gall number (GN), egg mass (EM), nematodes final population (FP), and factor of reproduction (FR) of tomato plants infected with Meloidogyne javanica and treated with fresh and fermented sisal liquid residue \{altura das plantas (PH), diâmetro do caule (SD), massa seca da parte aérea (SDW), massa seca de raízes (RDW), número de galhas nas raízes (GN), massa de ovos (EM), população final de nematoides (FP) e fator de reprodução (FR) de plantas de tomateiro infectadas por Meloidogyne javanica e tratadas com resíduo líquido de sisal, fresco e fermentado\}. Cruz das Almas, UFRB, 2012.

\begin{tabular}{lcccc}
\hline Sisal residue & PH $(\mathbf{c m})$ & SD $(\mathbf{c m})$ & SDW $(\mathbf{g})$ & RDW $(\mathbf{g})$ \\
\hline Fresh & $79.55 \mathrm{a}$ & $0.73 \mathrm{a}$ & $7.36 \mathrm{a}$ & $1.20 \mathrm{a}$ \\
Fermented & $74.48 \mathrm{~b}$ & $0.73 \mathrm{a}$ & $5.89 \mathrm{~b}$ & $1.18 \mathrm{a}$ \\
\hline & GN/plant & GN $/$ g root & EM/plant & \\
\hline Fresh & $181.9 \mathrm{~b}$ & $10.2 \mathrm{~b}$ & $49.9 \mathrm{~b}$ & \\
Fermented & $238.6 \mathrm{a}$ & $16.2 \mathrm{a}$ & $91.5 \mathrm{a}$ & \\
\hline & $\mathbf{E M} / \mathbf{g}$ root & FP & FR & \\
\hline Fresh & $2.6 \mathrm{~b}$ & $11026.7 \mathrm{a}$ & $2.7 \mathrm{a}$ & \\
Fermented & $6.3 \mathrm{a}$ & $6185.7 \mathrm{~b}$ & $1.5 \mathrm{~b}$ & \\
\hline
\end{tabular}

Mean values with the same letter do not differ (Scott \& Knott, $5 \%$ ) \{valores médios seguidas de letras iguais não diferem (Scott \& Knott, $5 \%)\}$. and that with the synthetic nematicide in the immobility of $M$. javanica shows that the sisal residues are more effective when used in the concentrations higher or equal to $7.5 \%$. For nematode mortality after $48 \mathrm{~h}$ exposure to either fresh or fermented residue, at the higher concentrations of $16 \%$ and $20 \%$, here was no significant difference $(\mathrm{p} \leq 0.01)$ between the residues and the synthetic nematicide for nematode control. These results demonstrate the sisal residue nematicidal activity and its potential for controlling $M$. javanica in tomato plants (Table 1). The fermentation process did not affect the nematicidal activity of this residue.

The sisal liquid residue anthelmintic efficacy has been demonstrated in vitro for lambs and goats gastrointestinal nematode eggs and larvae (Domingues et al., 2010; Silveira et al., 2012; Botura et al., 2013).

Meloidogyne javanica control in tomato plant with sisal residue - For the analyzed plant growth parameters (plant height, stem diameter, shoot and root dry weight), there were no significant effects $(p \leq 0.01)$ of the residue concentrations, for both fresh and fermented residues, and no interaction between the concentrations and type of residues. A significant difference in plant growth was observed for residue type. Plants treated with fresh residue had higher height and shoot dry weight when compared to those treated with fermented residue (Table 2). The treatments did not have any effect on stem diameter and root dry weight.

A comparison of the effects of sisal residues and the synthetic nematicide in plant growth, showed that the nematicide caused a reduction in all plant growth parameters (plant height, stem diameter, shoot and root dry weight), for all concentrations tested (Table 1). Plants treated with the synthetic nematicide showed symptoms of phytotoxicity, with wilted and dried leaves, and reduced growth, even though the concentration applied was four times lower than that used by Nasu et al. (2010). The phytotoxicity effect may be associated with the application method used in our study. The nematicide was applied in the soil after the tomato plants had been 
Table 3. Selectivity of fresh and fermented residue on beneficial soil microorganisms (seletividade de resíduo fresco e fermentado em microorganismos benéficos de solo). Cruz das Almas, UFRB, 2012.

\begin{tabular}{lcc}
\hline \multirow{2}{*}{ Microorganisms } & \multicolumn{2}{c}{ Sisal liquid residue } \\
\cline { 2 - 3 } Penicillium citrinum & Fresh & Fermented \\
Trichoderma atroviride & + & + \\
T. harzianum & + & - \\
T. virens & + & - \\
BFT4 & + & - \\
BFT7 & + & - \\
BFT11 & + & - \\
BFT41 & + & - \\
BFT71 & + & - \\
BFT87 & + & - \\
BFT88 & + & - \\
BFT102 & + & - \\
BFT106 & + & - \\
PD3 & + & - \\
\hline
\end{tabular}

The signs indicate presence $(+)$ or absence $(-)$ of microbial growth in culture media amended with sisal liquid residue os sinais indicam presença $(+)$ ou ausência (-) de crescimento microbiano em meio de cultura composto por resíduo líquido de sisal $\}$.

transplanted. Nasu et al. (2010) tested cassava processing wastewater and the nematicide Carbofuran (Furadan 350 $\mathrm{SC}$ ) in tomato plants. However, these authors applied the treatments to the soil infested with $M$. incognita and the tomato plants were transplanted 4 days after treatment application. Santos et al. (2013) used organic compounds and the Carbofuran nematicide (Furadan $350 \mathrm{SC}$ ) in soil with $M$. javanica and after 4 days the banana plants were transplanted. These authors did not observe phytotoxic effect when the nematicide and the agricultural residues were applied before having transplanted the tomato and banana plants.

Lopes et al. (2005) used leaf application of extracts from velvet bean plants and basil plants for control of $\mathrm{M}$. javanica and $M$. incognita in tomato plants and observed that these extracts did not affect plant height and shoot fresh weight, when compared to the control treatment. It is suggested that the low concentrations of sisal residue and the low quantities applied per plant may not have provided nutrients sufficient to promote plant growth.

This experiment was repeated twice plant. However, this high percentage of root gall reduction is associated with the reduced root growth due to the phytotoxic effect of this nematicide on the tomato plants.

The number of egg masses per plant also reduced with the treatments with both fresh and fermented residues, at all concentrations, when compared with the control with water. A reduction of $95 \%$ and $92 \%$ in the number of egg masses per plant was obtained with the application of the estimated concentrations of approximately $14.2 \%$ (fresh residue) and $13.1 \%$ (fermented residue), as compared to the control without the residue ( $0 \%$ ) (Figure 2A).

Considering the number of egg masses per gram of roots, significant reductions were also obtained with a decrease of $95 \%$ and $97 \%$ with soil application of the estimated concentrations of approximately $13.1 \%$ (fresh residue) and 14.4\% (fermented residue), compared to the control without the residue ( $0 \%$ ) (Figure 2B).

There was a significant reduction in the number of root galls and, especially in the number of egg masses per gram of roots, with only one application of the sisal liquid residues, fresh and fermented. For the fresh residue, for all tested concentrations, the number of egg masses per gram of roots was lower then that observed for the treatment with the nematicide. It is highlighted that the eggs are a type of inoculum and can be disseminated and hatch to release infective second stage and cause new infections (Agrios, 2005). Therefore, the significant reduction in the egg masses can represent an interruption of the nematode life cycle, and as a result, the control of root galls and nematode population in soil.

The quadratic model obtained for the effect of sisal residue concentrations on the nematode final population and the factor of reproduction (FR) indicates the tendency for the reduction of this pathogen's reproduction with the application of increasing concentrations of both sisal residues (Figures 2C and D). The nematode lowest final population in soil treated with fresh residue was obtained for the residue concentration of $20 \%$, with a reduction of $58.6 \%$ of the 


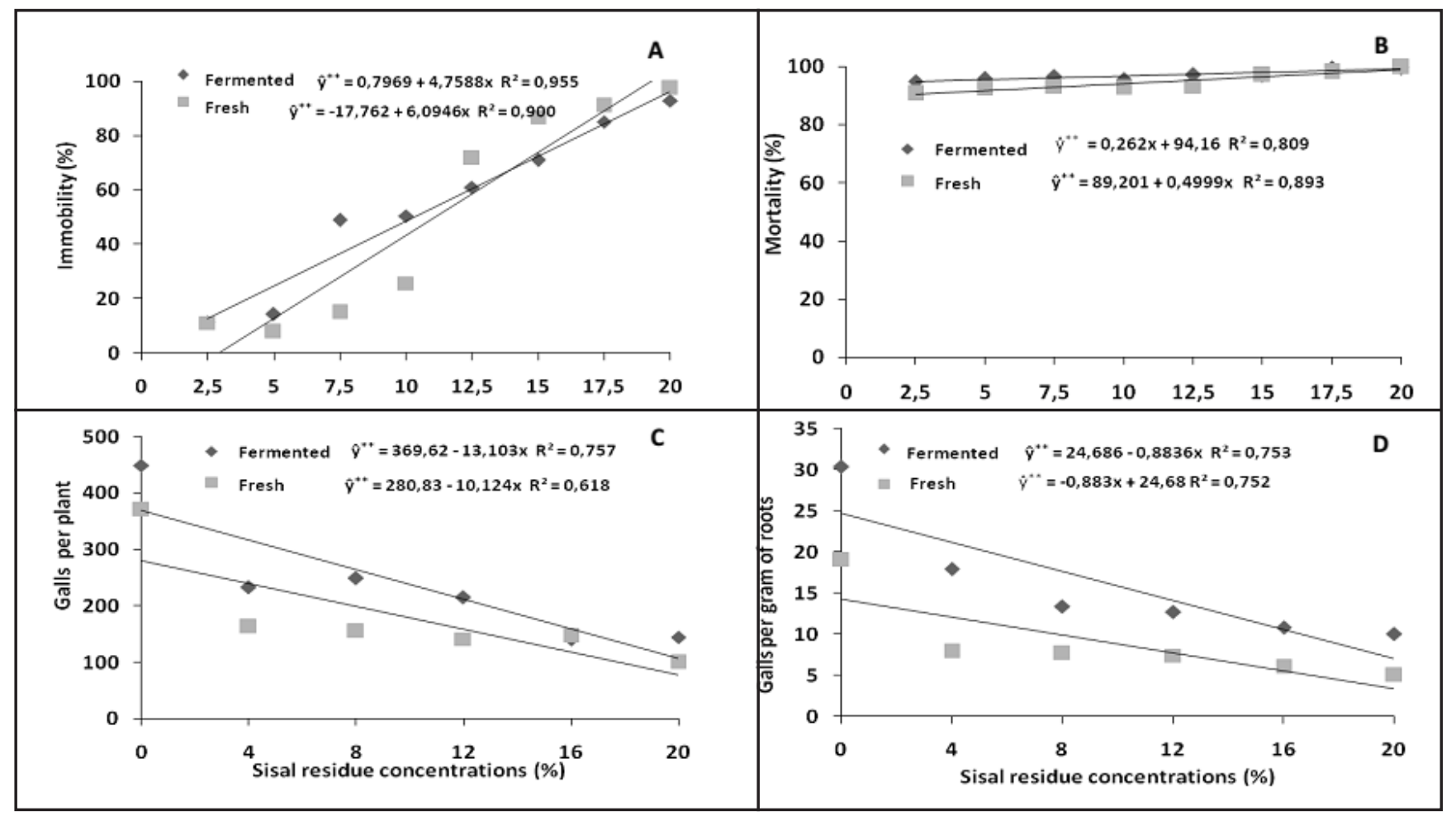

Figure 1. Control of Meloidogyne javanica with fresh and fermented sisal liquid residue, after in vitro exposure for $24 \mathrm{~h}$ (A) and $48 \mathrm{~h}$ (B), and under greenhouse conditions in tomato plants infected with $M$. javanica and treated with sisal residue: number of root galls per plant (C) and per gram of roots (D) \{controle de Meloidogynejavanica com resíduo líquido, fresco e fermentado, de sisal, após exposição in vitro por $24 \mathrm{~h}$ (A) e $48 \mathrm{~h}$ (B) e em condições de casa de vegetação em plantas de tomateiro infectadas com M. javanica e tratadas com resíduo de sisal: número de galhas por planta nas raízes (C) e por grama de raízes (D)\}. Cruz das Almas, UFRB, 2012.

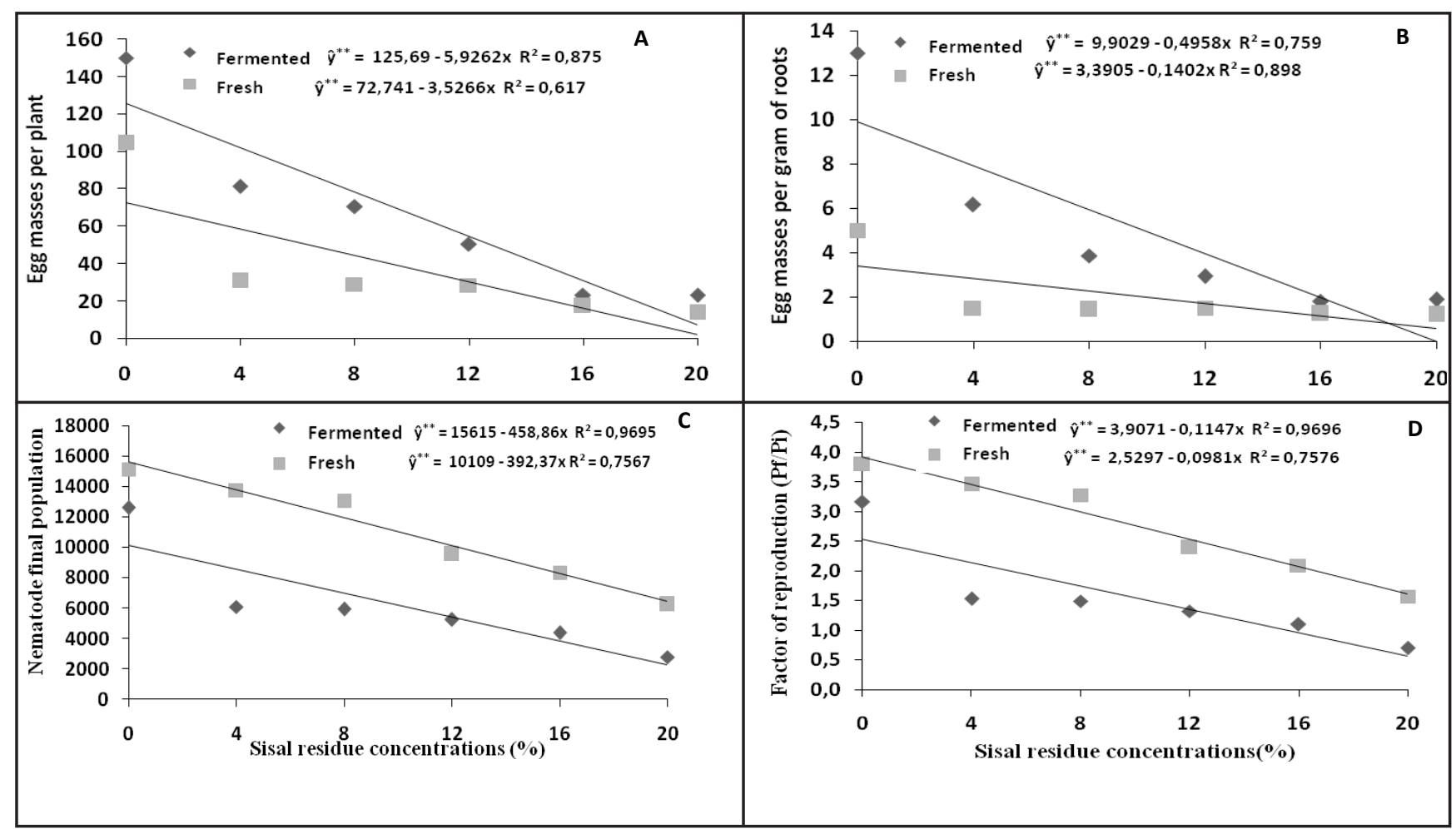

Figure 2. Egg masses per plant (A); egg masses per gram of roots (B); nematode final population (C) factor of reproduction (D) of Meloidogyne javanica in soil with tomato plants treated with sisal liquid residue, fresh and fermented (massa de ovos por planta nas raízes (A), massa de ovos por grama de raízes (B) população final de nematóides (C), fator de reprodução (D) de Meloidogyne javanica em solo com plantas de tomateiro tratadas com resíduo de sisal, fresco e fermentado\}. Cruz das Almas, UFRB, 2012. 
nematode population and a reproduction factor of 1.62, which is significantly different $(\mathrm{p} \leq 0.01)$ from the control treatment without the residue $(0 \%)$. However, for the fermented residue, a lower final population in soil and lower reproduction factor were found for all tested concentrations, which were also significantly different $(\mathrm{p} \leq 0.01)$ from the control treatment $(0 \%)$. The final population reduction varied from $54.7 \%$ to $71.7 \%$ for concentrations of $4 \%(\mathrm{FR}=$ 1.52) up to $20 \%(\mathrm{FR}=0.70)$, compared to the control without residue $(\mathrm{FR}=$ 3.15) (Figures 2C and D).

The reduction in the number of egg masses per gram of roots and in the nematode final population, observed at the in vivo tests, and the significant and rapid effect of sisal residue in the immobility and mortality of $M$. javanica indicate that this liquid residue, when applied to soil, may contribute significantly for the reduction of plant damage caused by $M$. javanica. Obviously, with the reduction of inoculum in soil and plants, a reduction in plant damage caused by this nematode should be observed.

The evaluation of plants treated with the synthetic nematicide and with the residues (fresh and fermented) indicates that the nematicide was more efficient, compared to the sisal liquid residues, for all tested concentrations, for the reduction of the number of galls per plant and per gram of roots, and also for the reduction of the final population of $M$. javanica and the factor of reproduction. The number of egg masses per plant did not differ significantly $(\mathrm{p} \leq 0.01)$ for the treatments with the nematicide and the treatments with the residues at the concentrations of $16 \%$ and $20 \%$. Between these treatments there was no significant difference for the number of egg masses per gram of roots, for all tested concentrations (Table 1).

The results obtained with the in vitro and in vivo experiments have clearly demonstrated that the sisal liquid residues, fresh and fermented, have nematicidal activity and can control $M$. javanica in soil and tomato plants. Several authors have reported the effects of extracts from different Agave species in the control of many pathogens (Guleria \& Kumar, 2009; Barreto et al., 2010; Domingues et al., 2010; Silveira et al., 2012; Botura et al., 2013). However, studies about the use of Agave sisalana for plant parasitic nematode control are scarce. Future studies should evaluate, throughout the entire cropping cycle in the field, the concentrations and the time intervals between liquid residue applications, as well as its residual effect for subsequent crops, for determining efficient methods of sisal residue application for controlling Meloidogyne spp. in tomato field cropping systems.

The nematicidal effect observed in this study may be associated with the activity of secondary metabolites, such as saponins, tannins and flavonoids, which are present in the sisal residue, and have been related to biological activities (Barreto et al., 2010; Botura et al., 2011, 2013). Homoisoflavonoids and saponins isolated from sisal residue showed anthelmintic activity against gastrointestinal nematodes of goats (Botura et al., 2013). The saponins present in the aqueous fraction of $A$. sisalana interact with the nematode cuticle proteins, promoting the nematicidal effect (Argentiere et al., 2008).

Olabiyi (2004) demonstrated that substances present in the roots of Hyptis suaveolens and Ocimum gratissimum, and in leaves of Tagetes erecta have saponins and flavonoids that reduce $M$. incognita population in tomato plants. Maistrello et al. (2010) observed for in vitro and in vivo testes that condensed tannins can control M. javanica.

These metabolites present in the sisal residues might have caused nematode mortality and inhibition of egg hatching. In addition, the different phases involved in the egg hatching process, such as cell division and proliferation, embryonic development, cuticle exchange and egg release may be differently affected by the metabolites and their concentration in the residues (Campos et al., 2001). Also, disorientation of root-knot nematode juveniles can occur, altering their ability to find the root system. Therefore, it is also suggested that a reduction and/or a delay in nematode root penetration could have caused the reduction in the number of root galls and egg masses, as described by Hewlett et al. (1997).

Selectivity of sisal liquid residue to beneficial microorganisms - The sisal fresh liquid residue did not inhibit growth of soil beneficial microorganisms. However, only Penicillium citrinum was able to grow in culture media amended with fermented residue, for all tested concentrations (Table 3).

Microorganisms are essential to agricultural systems, because of their important role in the biogeochemical cycles and organic material cycling. Moreover, microbial communities may promote root growth, produce plant growth promoting substances and promote better nutrient absorption by plants (Reis et al, 2010). These microorganisms can also act as biological control agents against plant parasitic nematodes (Molina \& Davide, 1986; Damasceno, 2011; Freitas et al., 2012). In the present study, soil microorganisms grow well in the presence of sisal fresh residue, for all tested concentrations.

The results of this study indicate the potential of sisal liquid residue, either fresh or fermented, for the control of M. javanica in tomato plants. The fresh residue did not present a negative effect on growth of soil microorganisms that had been selected in other studies as beneficial for plant growth and for biological control of different plant diseases. However, the fermented residue inhibited the in vitro growth of these microorganisms, indicating that it may cause a negative impact on soil microbial communities. Yet, the fermented residue presents several advantages with regard to storage and transportation, since it does not require refrigeration or other conservation methods. Future studies should be conducted to confirm the nematicidal activity of this agricultural residue for the control of $M$. javanica in tomato cropping systems, as well as the adequate methods for its application and its impact on soil microbial communities.

\section{REFERENCES}

ARGENTIERI MP; D’ADDABBO T; TAVA A; 
AGOSTINELLI A; JURZYSTA M; AVATO P. 2008. Evaluation of nematicidal properties of saponins from Medicargo spp. European Journal of Plant Pathology 120: 189-197.

BARRÊTO AF; ARAÚJO E; BONIFÁCIO BF. 2010. Eficiência de extratos de Agave sisalana sobre o ácaro rajado Tetranychus urticae (Koch) e ocorrência de fitotoxidez em plantas de algodoeiro (Gossypium hirsutum $\mathrm{r}$ latifolium). Revista Brasileira de Agroecologia 5: 207-215.

BONETTI JIS; FERRAZ S. 1981. Modificações do método de Hussey \& Barker para extração de ovos de Meloidogyne exigua, em raízes de cafeeiro. Fitopatologia Brasileira 6: 533.

BOTURA MB; SILVA GD; LIMA HG; OLIVEIRA JVA; SOUZA TS; SANTOS JDG; BRANCO A; MOREIRA ELT; ALMEIDA MAO; BATATINHA MJM. 2011. In vivo anthelmintic activity of an aqueous extract from sisal waste (Agave sisalana) against gastrointestinal nematodes in goats. Veterinary Parasitology 177: 104-110.

BOTURA MB; SANTOS JDG; SILVA GD; LIMA HG; OLIVEIRA JVA; ALMEIDA MAO; BATATINHA MJM; BRANCO A. 2013. In vitro ovicidal and larvicidal activity of Agave sisalana (sisal) on gastrointestinal nematodes of goats. Veterinary Parasitology 192: 211-217.

CAMPOS VP; CAMPOS JR; SILVA LHCP; DUTRA MR. 2001. Manejo de nematóides em hortaliças. In: SILVA LHCP; CAMPOS JR; NOJOSA GBA (eds). Manejo integrado de doenças e pragas em hortaliças. Lavras: UFLA. p. 125-158.

CANTU RR; WILCKEN SRS; ROSA JMO; GOTO R. 2009. Reaction of commercial rootstocks to Meloidogyne mayaguensis from tomato. Summa Phytopathologica 35: 216-218.

CHITWOOD DJ. 2002. Phytochemical based strategies for nematode control. Annual Review of Phytopathology 40: 221-249.

CONAB. 2013, 27 de maio. Sisal - safra 2012/2013: comercialização - proposta de ações. Disponível em: <http://www. conab.gov.br/OlalaCMS/uploads/ arquivos/12_10_29_11_45_31_sisal2012. pdf $>$.

DAMASCENO CL; SOARESACF; SAJO; SILVA RM; CARMO CO; SACRAMENTO ACSC. 2012. Antagonismo de Penicillium citrinum à Aspergillus niger, agente causal da podridão vermelha do sisal. In: XXXV CONGRESSO PAULISTA DE FITOPATOLOGIA, 38,
Resumos... Jaguariúna: SOB (CD-ROM).

DAMASCENO JCA. 2011. Actinobactérias na promoção de crescimento e controle de Meloidogyne javanica em mudas de tomateiro. Cruz das Almas: UFRB. 97p. (Dissertação mestrado).

DOMINGUES LF; BOTURA MB; CRUZ ACFG; YUKI CC; SILVA GD; COSTA MS; MURPHY G; MOREIRA ELT; MENESES IDS; ALMEIDA MGAR; BRANCO A; ALMEIDA MAO; BATATINHA MJM. 2010. Evaluation of anthelmintic activity of liquid waste of Agave sisalana (sisal) in goats. Revista Brasileira de Parasitologia 19: 270-272.

FREITAS MA; PEDROSA EMR; MARIANO RLR. MARANHÃO SRVL. 2012. Seleção de Trichoderma spp. como potenciais agentes de biocontrole para Meloidogyne incognita em cana-de-açúcar. Nematropica 42: 115-122.

GULERIA S; KUMAR A. 2009. Antifungal activity of Agave americana leaf extract against Alternaria brassicae, causal agent of Alternaria blight of Indian mustard (Brassica juncea). Archives of Phytopathology and Plant Protection 42: 370 -375.

HEWLETT TE; HEWLET EM; DICKSON DW. 1997. Response of Meloidogyne spp., Heterodera glycines and Radopholus similis to tannic acid. Journal of Nematology 29: 737-741.

HUSSEY RS; BARKER R. 1973. A comparison of methods of collecting inocula of Meloidogyne spp. including a new technique. Plant Disease Reporter 57: 1025-1028.

KERBOEUF D; RIOU M; GUÉGNARD F. 2008. Flavonoids and related compounds in parasitic disease control. Mini-Reviews in Medicinal Chemistry 8: 116-128.

LOPES EA; FERRAZ S; FREITAS LG; FERREIRA PA; AMORA DX. 2005. Efeito dos extratos aquosos de mucuna preta e de manjericão sobre Meloidogyne incognita e $M$. javanica. Nematologia Brasileira 29: 67-74.

MAISTRELLO L; VACCARI G; SASANELLI N. 2010. Effect of chestnut tannins on the root-knot nematode Meloidogyne javanica. Helminthologica 47: 48-57.

MOLINA GC; DAVIDE RG. 1986. Evaluation of microbial extracts for nematicidal activity against plant parasitic nematodes Meloidogyne incognita and Radopholus similis. Philippine Agriculturist 69: 173-186.

MORAIS LAS; MATTOS LPV; GONÇALVES GG; BETTIOL W. 2009. Efeito de diferentes concentrações do óleo de nim (Azadirachta indica) no crescimento micelial de fungos entomopatogênicos e Trichoderma harzianum. Horticultura Brasileira 27: 113-117.

NASU EGC; PIRES E; FORMENTINI HM; FURLANETTO C. 2010. Efeito de manipueira sobre Meloidogyne incógnita em ensaios in vitro e em tomateiros em casa de vegetação. Tropical Plant Pathology 35: 032-036.

NEVES WS; FREITAS LG; LOPES EA; COUTINHO MM; DALLEMOLEGIARETTA R; FERRAZ S. 2008. Efeito, in vitro, do extrato de sementes de mamão sobre a eclosão e juvenis de Meloidogyne spp. Revista Trópica Ciências Agrárias e Biológicas 2: 9-14.

OLABIYI TI. 2004. Assessment of the nematicidal properties of extracts from Tagetes erecta, Ocimum gratissimu, Hyptis suaveolous and Crotalaria retusa. Nigeria: University of Ilorin. 177p. (Thesis).

OOSTENBRINK M. 1966. Major characteristic of relation between nematodes and plants. Mededelingen Landbouwhogeschool 66: 1-46.

REIS VM; ANDRADE G; FARIA SM; SILVEIRA AOD. 2010. Interações de fungos micorrízicos arbusculares com outros mecanismos do solo. In SIQUEIRA JO; SOUZA FA; CARDOSO EJBN; TSAI SM (org). Micorrizas: 30 anos de pesquisa no Brasil. Lavras: UFLA.

SA JO. 2013. Controle biológico da podridão vermelha do sisal (Agave sisalana) com Trichoderma spp. e actinobactérias. Cruz das Almas: UFRB 133p. (Tese doutorado).

SANTOS BHC; RIBEIRO RCF; XAVIER AA; NETO JAS; MOTA VJG. 2013. Controle de Meloidogyne javanica em mudas de bananeira Prata-anã por compostos orgânicos. Revista Brasileira de Fruticultura 35: 650-656.

SCHENKEL EP; GOSMANN G; ATHAYDE ML. 2010. Saponinas. In: SIMÕES CMO; SCHENKEL EP; GOSMANN G; MELLO JCP; MENTZ LA; PETROVICK PR (org). Farmacognosia da planta ao medicamento. 6.ed. Porto Alegre: Editora da UFRGS; Florianópolis: Editora da UFSC. p. 711-734.

SILVEIRA RX; CHAGAS ACS; BOTURA MB; BATATINHA MJM; KATIKI LM; CARVALHO CO; BEVILAQUA CML; BRANCO A; MACHADO EAA; BORGES SL; ALMEIDA MAO. 2012. Action of sisal (Agave sisalana) extract in the in vitro development of sheep and goat gastrointestinal nematodes. Experimental Parasitology 131: 162-168.

SUINAGAFA; SILVA, ORRF; COUTINHO WM. 2006. Cultivo de sisal na região Semi-árida do nordeste brasileiro. Campina Grande: EMBRAPA Algodão. 42p. 